\title{
Igreja Divino Espírito Santo do Cerrado: diversas lembranças
}

\section{Resumo}

Este estudo foi desenvolvido na dissertação de mestrado "Um olhar sobre a Igreja Divino Espírito Santo do Cerrado", no intuito de abordar as diversas memórias envolvidas com a igreja, projeto de Lina Bo Bardi em Uberlândia/ MG. O conjunto religioso é considerado uma leitura de cultura popular e identidade do lugar, transcendendo-se em forma de arquitetura edificada.

Palavras-chave: comunidade cristã, afetividade, memória coletiva, cultura popular.

1 Lina preferia ser chamada de arquiteto.
2 Apenas membros frequentadores da paróquia. trabalho tem o intuito de analisar a temática da memória, de pessoas envolvidas com o conjunto arquitetônico da Igreja Divino Espírito Santo do Cerrado, em Uberlândia/MG. A partir de tal abordagem, o propósito foi de construir um novo olhar da pesquisadora, que é arquiteta urbanista por formação, através do contato e dos relatos dessas personagens, especialmente da comunidade local, que utiliza o espaço para práticas religiosas, com suas experiências e relações afetivas com o lugar, ao longo do tempo.

O projeto do "arquiteto"1 Lina Bo Bardi (19141992) foi edificado entre os anos de 1976 e 1982, no bairro Jaraguá, numa época em que a região estava em processo de ocupação, com vias ainda não pavimentadas. De iniciativa da Ordem Franciscana, o conjunto foi construído com elementos característicos do cerrado mineiro, como por exemplo, a madeira de aroeira, e erguido por sua própria comunidade, que esteve constantemente envolvida na obra através dos mutirões.

Único projeto de Lina Bo Bardi no estado, foi tombado em 1997 como patrimônio pelo Instituto

\section{Natalia Achcar Monteiro Silva}

Arquiteta e urbanista, mestre em Ambiente Construído e Patrimônio Sustentável pela Universidade Federal de Minas Gerais (MACPS UFMG), docente do Centro Universitário Metodista Izabela Hendrix, do Centro Universitário de Belo Horizonte (UNIBH) e professora convidada da Pontifícia Universidade Católica de Minas Gerais (PUC Minas), natyachcar@yahoo.com.br

\section{Maria Cristina Villefort Teixeira}

Arquiteta e urbanista, doutora em Planejamento Urbano pelo Instituto de Pesquisa e Planejamento Urbano da Universidade Federal do Rio de Janeiro, professora da Universidade Federal de Minas Gerais, Rua Paraíba 697, Funcionários, Belo Horizonte, MG, CEP 30130-140, mcrisvt@gmail.com

Estadual de Patrimônio Histórico e Artístico de Minas Gerais (IEPHA-MG), devido ao risco eminente de descaracterização, e entre os anos de 2009-2014 passou por processo de reforma e restauro, além da construção de um centro pastoral, em 2013, que se sobrepôs ao platô mais baixo - antigo campinho. Quem assina os projetos são os arquitetos Marcelo Ferraz e André Vainer, que trabalharam com Lina Bo Bardi e são considerados coautores da obra.

O intuito de abordar memória coletiva está em entender, em termos comunitários, como ela se mantém, transforma e adapta ao longo do tempo e das relações construídas entre as pessoas e delas com as edificações da igreja, repercutindo na forma de apropriação e pertencimento sociocultural e espacial.

Sendo assim, neste estudo o foco foi produzir e tratar depoimentos (entrevistas) gravados com um recorte de agentes que não se pautou por uma quantidade determinada de entrevistados; na verdade, a participação foi livre e aberta - aqueles que se sentiram confortáveis e se disponibilizaram a compartilhar suas lembranças e experiências². As entrevistas foram semiestruturadas com per- 
3 A informação foi disponibilizada pelo próprio Edmar de Almeida, em janeiro de 2014 - entrevista não gravada.
Figura 1: Croquis aquarelados do conjunto desenhos de Lina Bo Bardi. Fonte: BARDI; ALMEIDA; FERRAZ, 1999. guntas que foram construídas a partir do próprio contato com o entrevistado, mas de toda forma, possibilitaram outros desdobramentos além do previsto. Os entrevistados autorizaram o uso das informações e fotografias através de um "Termo de Consentimento Livre e Esclarecido".

\section{O conjunto arquitetônico da Igreja Divino Espírito Santo do Cerrado}

Em 1975, os Freis Egydio Parisi e Fúlvio Sabia convidaram Lina Bo Bardi para realizar o projeto de uma igreja franciscana no bairro Jaraguá - periferia de Uberlândia/MG. Por seu caráter religioso, inicialmente Lina Bo Bardi, que se considerava ateia e comunista, recusou o convite, mas, posteriormente aceitou por intermédio do artista plástico e seu amigo Edmar de Almeida, que alegou ter o conjunto uma intenção social e ser destinado ao povo ${ }^{3}$. O projeto foi doado pelo arquiteto à comunidade.

Construída entre 1976 e 1982, com participação dos próprios moradores através de mutirões nos finais de semana, foi edificada utilizando materiais característicos da região, angariados por doações. Todo o processo de construção da igreja, feito através do trabalho em comunidade, foi gestado por um "conselho de construção", eleito e composto por uma comissão de moradores. Também foi essencial a ajuda financeira vinda da organização católica alemã Adveniat, com sede em Essen.

A igreja foi construída por crianças, mulheres, pais de família, em pleno cerrado. Construída com materiais muito pobres, coisas recebidas de presente, em esmolas. É tudo dado. Mas não no sentido paternalista, mas com astúcia, de como pode se chegar a coisas com meios muito simples (BARDI, 1999).

As soluções construtivas aludem aos materiais da região, representando através da arquitetura, a cultura popular, uma produção característica do lugar e do povo miscigenado do cerrado mineiro, o que é, inclusive, abordado no Dossiê de Tombamento:

A simplicidade presente nesta construção não foi fruto apenas dos parcos recursos financeiros empregados na obra. Acima de tudo, estavam presentes traços de seu engajamento políticoideológico e arquitetônico, e que envolvia o trabalho com a comunidade local, o resgate de aspectos da genuína cultura popular, da compreensão e valorização de nosso enorme "caldeirão" cultural. Todos esses fatores fizeram com que a Igreja do Espírito Santo do Cerrado resultasse em uma obra singular. (IEPHA/MG, 1997, p.11).

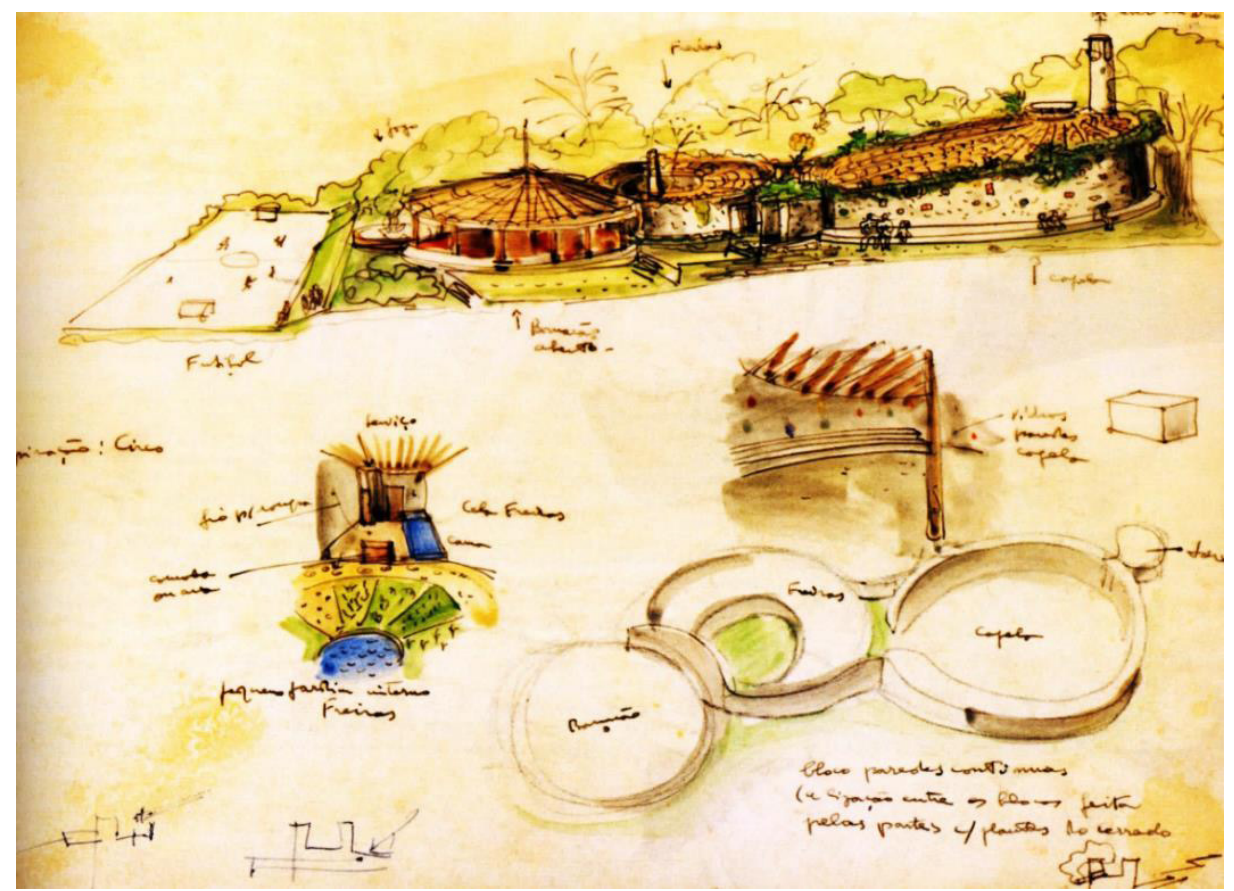


E segundo Ferraz(1997, p.173), os desenhos pensados por Lina são ainda mais simbolicamente explorados,

\section{[...] Ela realiza o ecumenismo através de seus espaços.}

[...] Nesse projeto você tem de um lado um terreiro de Candomblé completamente africano, do outro uma igreja franciscana de pequena cidade italiana. No meio um "caracol (os claustros), uma área de concentração, de camarim", até chegar ao centro com um pequeno lago, um poço árabe. Tudo isso cercado pelas plantas do cerrado, culminando com o campinho de futebol bem brasileiro. "Ela é uma igreja pra lá do catolicismo, é uma igreja pagã, ou católica panteísta".

Em termos de implantação, o conjunto se dispõe vencendo a topografia através de quatro platôs, compostos cada um (do mais alto para o mais baixo), respectivamente, pelo campanário e capela, a casa para três religiosas e um salão comunitário, além do campinho de futebol não existente mais. Nesse contexto, a hierarquia espacial vem para

4 Segundo o arquiteto Marcelo Ferraz, em entrevista realizada em outubro de 2013, a intervenção aconteceu para receber moradores que ficaram desabrigados com a chuva.

Figura 2: Fotografia do conjunto entregue na década de 1980. Fonte: BARDI; ALMEIDA; FERRAZ, 1999 vencer o desnível do terreno, as edificações estão dispostas em três plantas circulares integradas. Seus volumes são relativamente baixos, permeando-se pela paisagem residencial de um ou dois pavimentos, o que é ainda mais potencializado pelos materiais empregados, assim como as dimensões modestas e no limite do necessário. A organicidade e disposição dos espaços trabalham as sensações e percepções, ora com refúgio e meditação, ora com sentido de coletividade. Na proposta original, não existiam "fechamentos" no conjunto em relação à cidade: a ideia era justamente que interior e exterior se integrassem harmoniosamente, pois a igreja era, antes de tudo, da comunidade.

O acesso frontal do conjunto acontece na Avenida dos Mognos. As edificações são compostas por telhado com estruturação de madeira e telhas coloniais no sistema "capa-e-canal", as instalações elétricas e hidráulicas, assim como a estrutura em madeira de aroeira e/ou concreto armado, ficam expostas. A capela com campanário foi pensada, externa e internamente, em tijolos aparentes assen-tados com barro e sem reboco, tendo concreto armado apenas onde necessário para estruturação, em vigas e pilares. Intervenções posteriores, em meados dos anos de 1990, resultaram em reboco e pintura no interior da capela. A dependência das freiras, com celas mínimas, tem exterior em tijolos aparentes e interior e claustro com reboco e pintura branca.

Já o salão comunitário remetia a uma oca indígena, inicialmente todo aberto e com chão batido, recebendo, após uma enchente 4 , fechamento em meia-altura com bambus; posteriormente o piso foi cimentado e a vedação do piso à cobertura alterada para toras finas de madeira. Já o campinho foi pensado em grama, recebendo cimento, também nos anos de 1990 e na contemporaneidade substituído pelo edifício do centro pastoral.

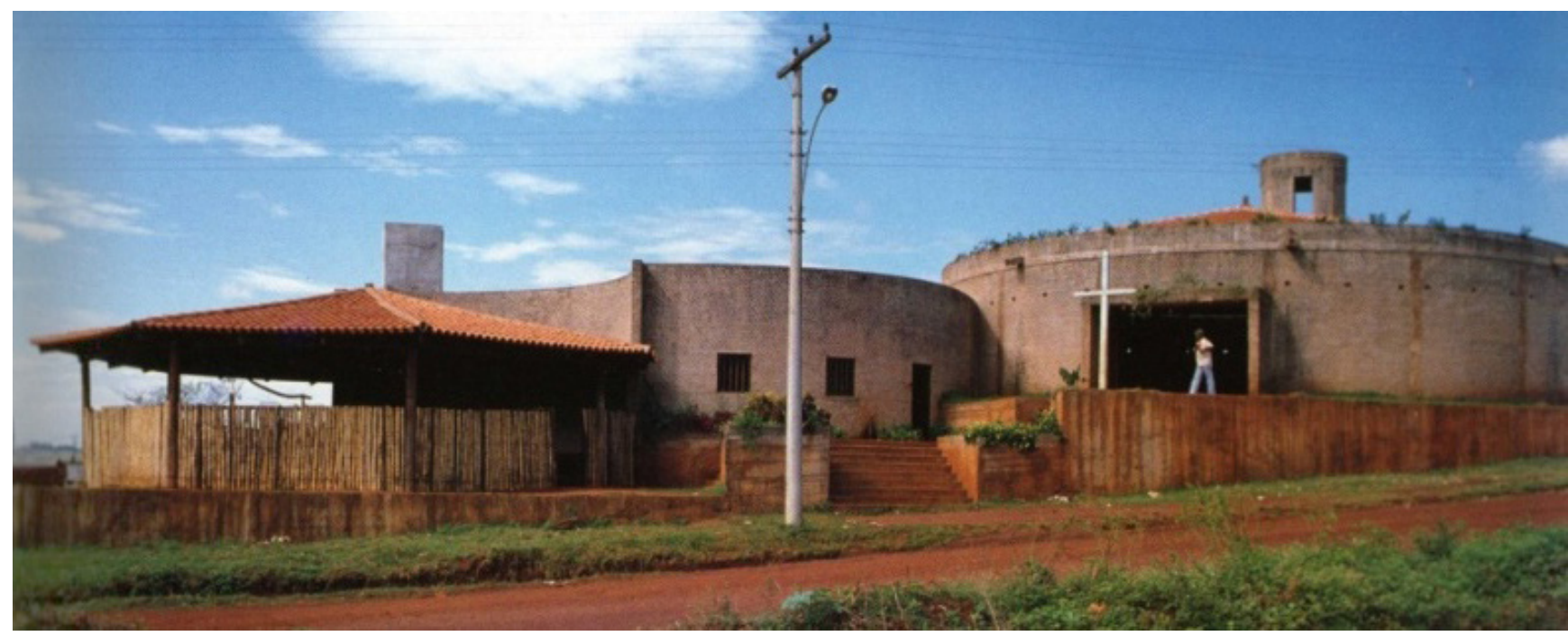



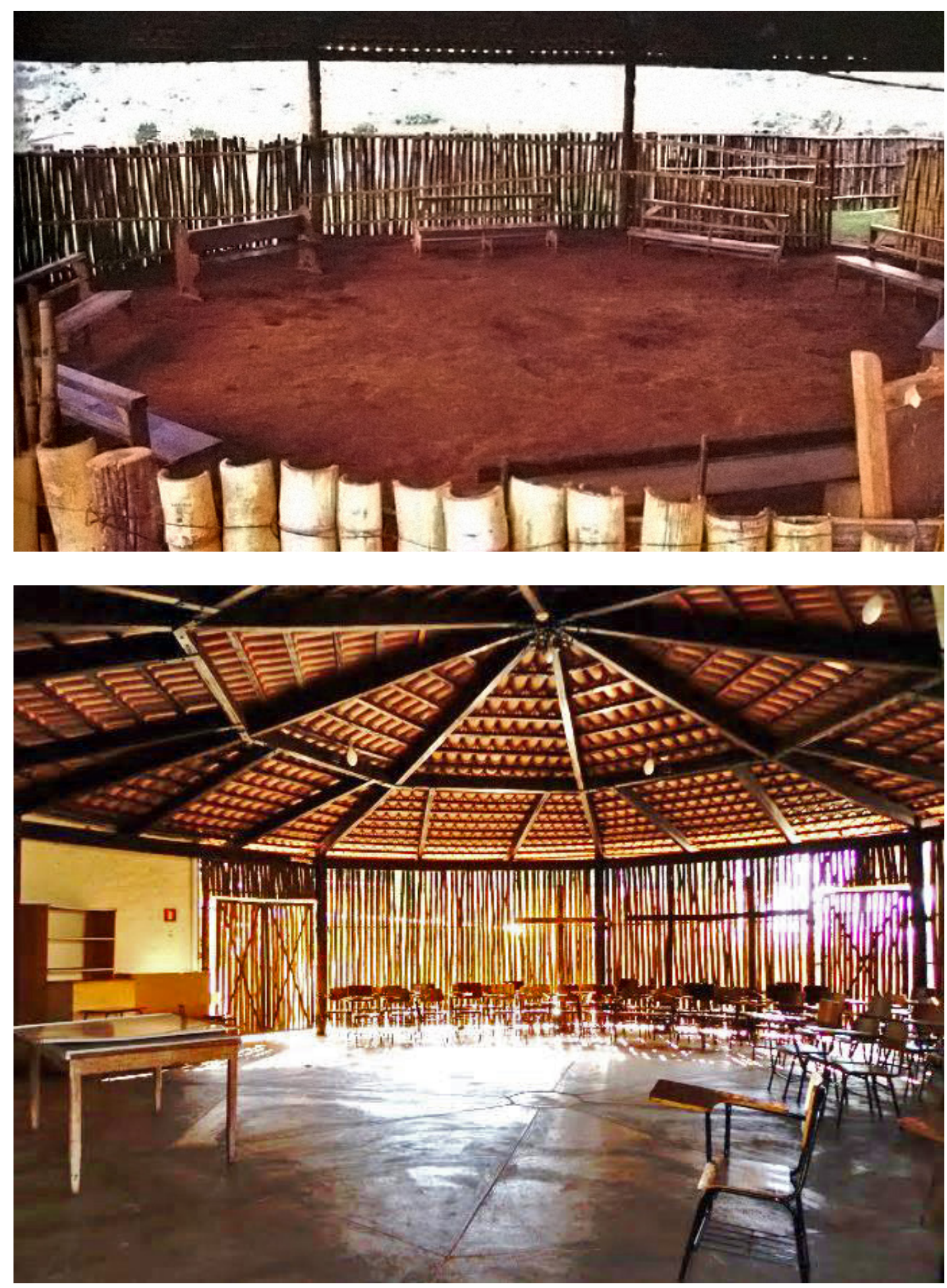

Figura 3 (topo): Centro Comunitário nos anos de 1980 Fonte: BARDI; ALMEIDA; FERRAZ, 1999

Figura 4: Centro Comunitário na atualidade. Fonte: Arquivo pessoal, 2013. 
5 Disponível em: <uberlandia. mg.gov.br/?pagina=Conteudo\&id=428>. Acesso em: 01 jul. 2013

6 Não mais encontradas na região.

7 Padre Márcio não é mais o pároco desde 2014.

Figura 5: Fotografia atual após entrega do projeto de ampliação e restauro. Fonte: Arquivo pessoal, 2014
Em termos de proteção, apesar de, em 27 de fevereiro de 1991, a igreja ter sido protegida como patrimônio municipal pela lei $n^{\circ}$. $5207^{5}$, o mesmo parecia não ter ocorrido. Foi somente em maio de 1997, quando se tornou patrimônio histórico estadual pelo IEPHA-MG, que o processo preservacionista ganhou maior força.

Com obras de 2009 a 2014, a igreja passou por proces-so de restauração e reforma, sob supervisão do IEPHA-MG, e quem assinou o projeto, foram os arquitetos Marcelo Ferraz e André Vainer, que trabalharam com Lina Bo Bardi na proposta original, considerados, portanto, coautores. Dentre as características gerais, foi construído um anexo para a administração e pastoral, como já citado, que ocupa o nível mais baixo na Avenida dos Ipês, onde anteriormente havia o campo de futebol. Essa edificação possui um terraço superior onde são realizadas as festividades da igreja, sendo que, sua arquitetura é bastante diferente do restante do conjunto e alterou consideravelmente a permeabilidade e fluidez proporcionadas pelo escalonamento dos platôs e pelas baixas altimetrias das edificações.

A capela, que também já foi modificada ao longo do tempo, possui cinco vigas em madeira de pau brasil, substituindo as danificadas em aroeira ${ }^{6}$, e o reboco interno foi mantido, exceto pelo altar que retomou as características iniciais, pois representantes do IEPHA-MG consideram que a alteração já foi apropriada pelos usuários.

Na casa das freiras, as alterações mais significativas estão na mudança do piso em madeira para cimento, conforme previsto no projeto original e a transformação de duas celas mínimas em um único espaço, onde serão armazenados materiais das pastorais. Uma das celas menores e outra de maiores dimensões foram mantidas.

De modo geral, segundo o pároco padre Márcio Antônio Gonçalves ${ }^{7}$, o intuito da reforma e restauro foi de finalizar o que foi pretendido na proposta original e retomar as caracterizações consideradas relevantes.

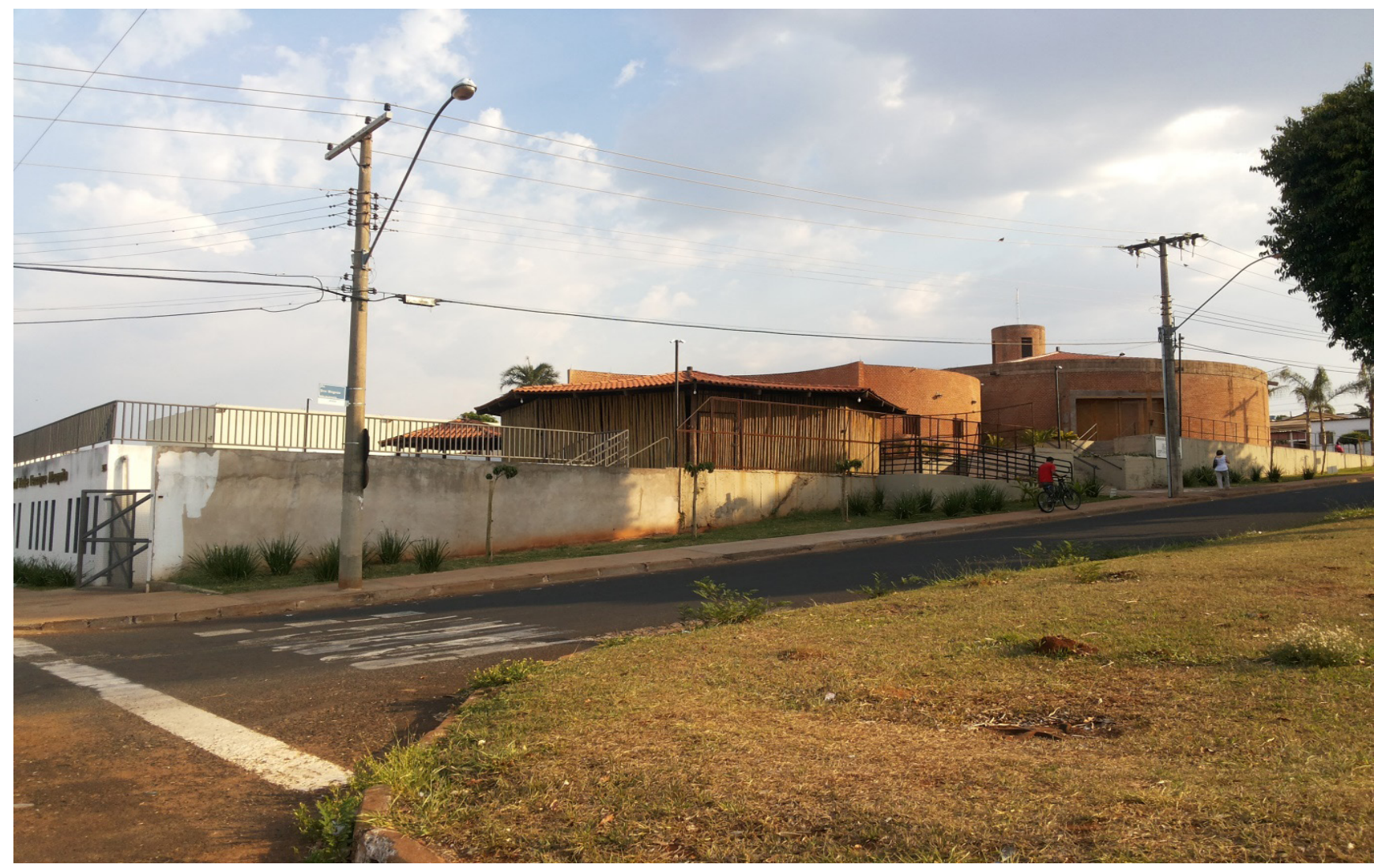




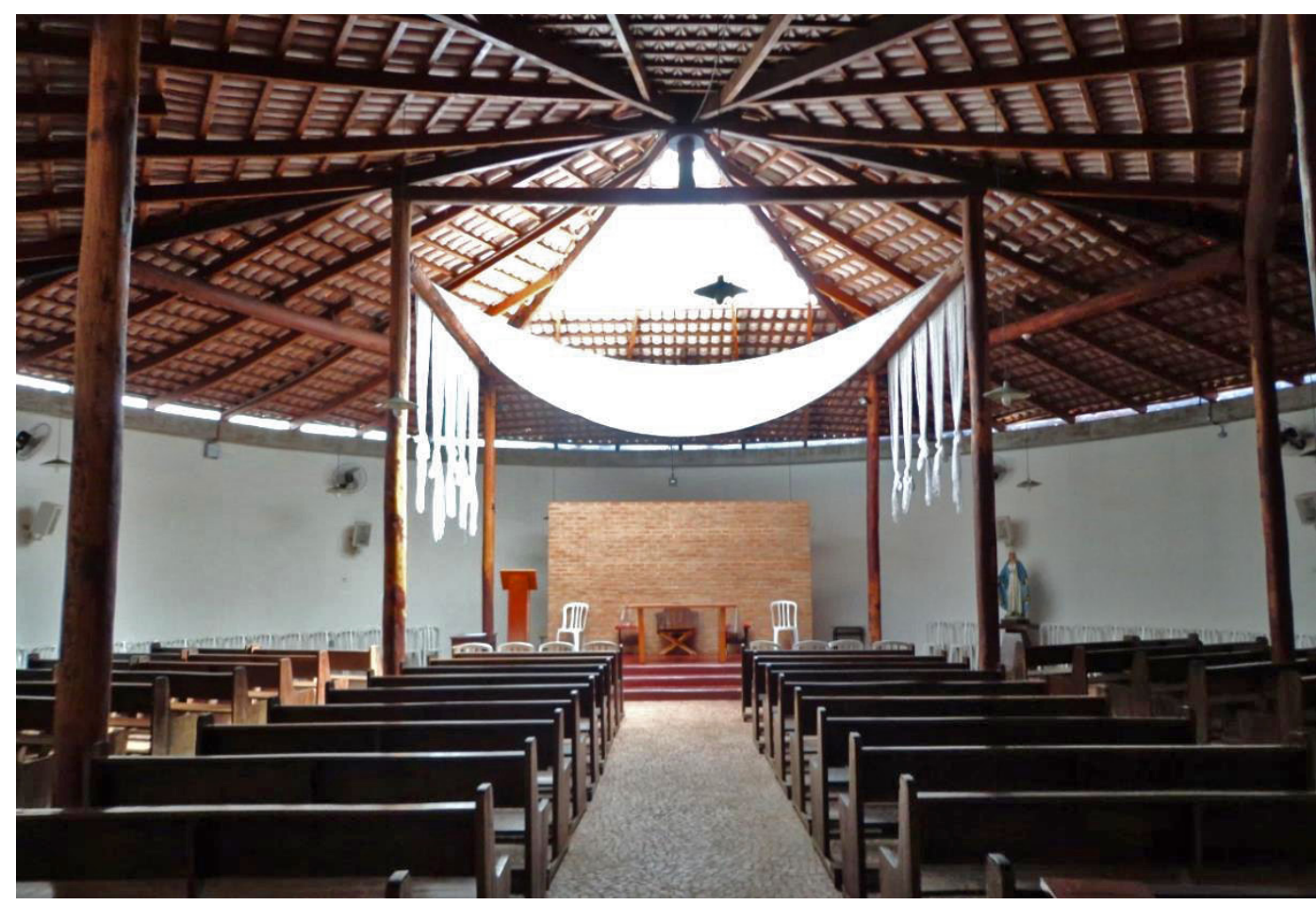

Figura 6: Fotografia atual do altar, em tijolos aparentes. Fonte: Arquivo pessoal, 2014.

\section{As diversas lembranças}

O contato próximo com membros da comunidade e outros agentes envolvidos com a Igreja Divino Espírito Santo do Cerrado proporcionou uma coletânea de lembranças e percepções que expressam o que foi edificado, tanto em termos físicos, como simbólicos e afetivos. Com relação à comunidade, como a pesquisa é qualitativa, não houve um recorte prédefinido de entrevistas, com isso, contribuíram aqueles que se sentiram à vontade para compartilhar suas lembranças ou que tinham disponibilidade quando do contato da pesquisadora.

De acordo com Marcelo Ferraz, em termos de localização, o conjunto religioso foi implantado em uma região, que na época, era periferia da cidade, situação que mudou com o tempo e os processos de expansão urbana.

Aquela comunidade da igreja, quer dizer, daquele bairro, mudou muito. Quando a gente fez a igreja com a Lina, aquilo era, a gente podia dizer, que era a periferia de Uberlândia... não era calçado, todas as ruas eram de terra, não tinham muros, não tinha calçada, então, era um bairro, de certa maneira, periférico e um pouco abandonado, o resto de cidade. [...] Mas mudou, porque também as cidades brasileiras mudaram, Uberlândia cresceu enormemente, é uma cidade gigante, está tudo asfaltado, tem muros. (FERRAZ, 2013. Informação verbal.)

Essas mudanças também refletiram no corpo social do lugar ao longo desses mais de 30 anos, mas ainda mantendo muitos dos seus moradores das décadas de 1970-80, o que foi verificado no trabalho de campo. Outra transformação é em relação à espiritualidade, alguns membros mudaram de religião, se desligando das atividades da igreja católica e consequentemente, não reconhecendo mais que o conjunto tem caráter comunitário, apesar do cunho também religioso. Sendo assim, mesmo o espaço que foi destinado à comunidade não tem uma apropriação generali-zada, resultando mais em atividades da própria paróquia.

\section{A comunidade e a afetividade}

Em termos de atuação, segundo Frei Fúlvio, desde o início a comunidade se envolveu na construção 
do conjunto, buscando recursos financeiros para as obras, além de participar dos mutirões aos domingos.

[...] acho que é interessante de você saber. Nós íamos ter uma ordenação sacerdotal, o moço que ia ser ordenado escolheu essa Igreja, apesar dela não ser muito grande, mas ele não - "eu vou, eu quero ser ordenado lá", tudo bem, então, mas, não tinha nem o piso, o piso era de chão batido, terra, aí, "o que nós vamos fazer, não tem dinheiro, né?", ah, fomos numa fábrica de balas, balinhas, e 'pediu' (sic) os sacos vazios de açúcar, né. Ela me deu, a fábrica de balas Erlan, né, me deu [...] 500 sacos, aí entregamos esses sacos para o povo, o povo clareou, porque tinha escrita [...], cortou, cada saco deu dois panos de prato, fizemos mil sacos, mil panos de prato, bordado, tudo bonitinho, vendemos né, fizemos o piso. O povo que fez, o povo que fez, essa é a coisa interessante. (SABIA, 2013. Informação verbal.)

O frei ainda destaca a participação comunitária nas diversas atividades da Paróquia, o que enfatiza ser compatível com o discurso dos franciscanos, especialmente, em termos de pertencimento.

Figura 7: Parte da carta convite à comunidade do bairro Jaraguá, para participação nas obras de construção do conjunto da igreja - data indefinida. Fonte: IEPHA/MG, 1997, p.138
Sempre, sempre, sempre, esse é um pouco nosso estilo também, é, teve sempre o Conselho da Paróquia que animava e organizava junto comigo o trabalho da comunidade, [...] a Catequese, eles que organizavam, as Pastorais dos Doentes, [...] a manutenção da Igreja, eles que limpavam, que enfeitavam, eles que arrumavam, [...] então, a comunidade, continuamente, tentava sempre envolver, porque é também o meu estilo, eu gosto de que o povo se sinta dono do lugar, da Igreja, das estruturas. (SABIA, 2013. Informação verbal.)

Padre Márcio ressalta que a comunidade cresceu e os espaços edificados já não atendiam mais as necessidades, e aponta que, ainda nos dias de hoje, a comunidade continua engajada e participativa, mantendo esse envolvimento de caráter coletivo.

Então, quando a Lina fez o projeto desse complexo, que é a Igreja, a casa e o salão, ela atendeu a uma realidade, a uma demanda daquele momento. A comunidade era extremamente participativa, envolvida nas atividades da igreja, a própria ideia da construção, na modalidade de mutirões, traduz essa dimensão. Hoje, quem visita, e nós recebemos muitas visitas à igreja, tanto de estudante de Universidades do Brasil, como estudantes de fora, [...] vê que é outra realidade, a cidade cresceu e o bairro aqui também cresceu muito, a comunidade também, em consequência, conheceu seu crescimento. Mas é uma comunidade que ainda mantém esse traço da sua história, é uma comunidade participativa, envolvida nas atividades. Hoje, coincidentemente, você está visitando a preparação do espaço para

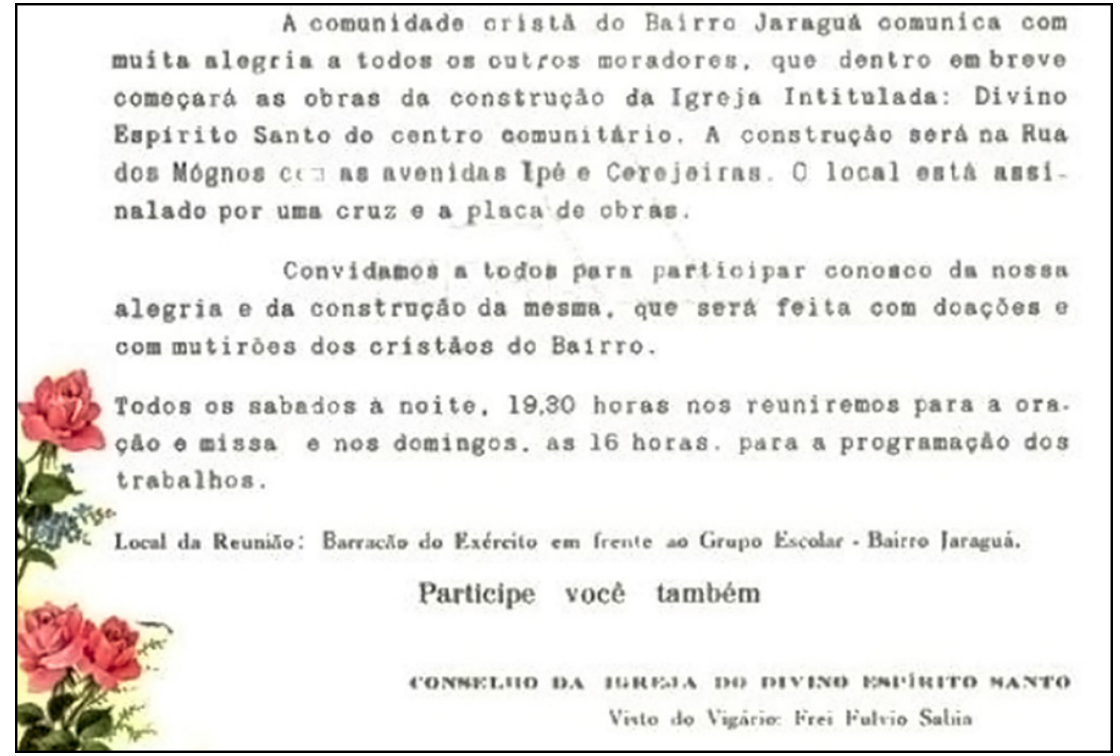


8 Com a Festa do Divino Espírito Santo realizada em maio de 2013, a comunidade conseguiu recursos e os bancos foram comprados. A substituição dos antigos aconteceu no final de janeiro de 2014.

$9 \mathrm{D}$. Ana Maria se refere às goteiras no telhado da Igreja, resultantes, segundo Edmar de Almeida em entrevista não gravada, de um erro de execução por parte do Sr. Alfredo, mestre de obras, que não seguiu as especificações de Lina Bo Bardi. uma festa comunitária, a festa do Divino, Divino Espírito Santo, e é uma festa que visa angariar recursos para nós colocarmos bancos novos na igreja ${ }^{8}$. Então, de modo geral, as pessoas são bem participativas. A ideia desde o início da comunidade, de criar espaços de cuidado, de promoção da vida, é algo que é preservado. Então, tem o trabalho da pastoral da criança, tem trabalho de confecção de fraldas geriátricas para as pessoas carentes, então, o espaço ali da casa, que foi concebido pela Lina, é um, é espaço hoje muito voltado 'pra' (sic) essa dimensão humanitária. (GONÇALVES, 2013. Informação verbal.)

Com relação à afetividade, alguns dos entrevistados salientaram o que pensam sobre a arquitetura edificada. D. Ana Maria chamou atenção para o fato de ter sido necessário tempo e conhecimento para que tivesse apreço pela edificação.

O altar já está maravilhoso, o altar era o antigo né, e eu só fiquei contrariada, porque hoje eu penso, hoje o valor que eu dou, eu era estressada também com ela, igual eu te falei, chovia demais ${ }^{9}$. Mas hoje a gente vê o valor assim, tanto que o povo admira 'ela' (sic), e gosta e acha bonito, que a gente também, entrosou [...]. Só que eu achei ruim, foi as 'parede' (sic) né, podia ter deixado do jeito que 'tava' (sic) né, rústica [...], que agora não tem como tirar [...], porque se tirar agora vai estragar o tijolinho todinho. Mas o altar como que foi demolido né, então aí fez outro, aí ficou lindo [...]. Eu sei que essa igreja, ela é famosa, e todo mundo é apaixonado nessa igreja, eles 'chega' (sic), tem uns que até 'chora' (sic), de ver o tanto que ela é bonita, engraçado né, às vezes é porque a gente não entende muito de obra. (SANTOS, 2014. Informação verbal.)

D. Ana Alice tem relações mais fortes e estabelecidas de pertencimento.

Ah, eu amo isso ali! Nossa! 'Pra' (sic) mim é tudo de bom, bom mesmo sabe, vou nas outras Igrejas, assim, sabe, acho linda, maravilhosa, mas sabe quando 'cê' (sic) acha a casa do vizinho linda, mas 'cê' (sic) gosta é da sua, então, é isso. (PINTO, 2014. Informação verbal.)

D. Sonia se mostra a favor da preservação dos edifícios, apesar de sugerir alterações na Capela.
Eu 'acho ela' (sic) maravilhosa! Sempre achei! Sempre quando alguém fala "ah!.. mas tinha que mudar", eu sou totalmente contra, eu 'acho ela' (sic) linda, sabe, eu gosto muito dela, a única coisa que eu achava que tinha que mudar um pouco, assim, era colocar mais uma porta, porque tem uma porta só, [...] mas eu acho que num pode 'né' (sic), por causa do projeto não pode, mas eu acho ela maravilhosa, a lgreja. Eu gosto muito. (TUNDISI, 2014. Informação verbal)

D. Conceição diz gostar da arquitetura, principalmente, considerando-a diferente do convencional e comenta que, ao mesmo tempo em que há moradores da comunidade que não tem este mesmo apreço, em contrapartida, outras pessoas de lugares variados a escolhem para a realização de eventos religiosos, justamente por sua excepcionalidade.

Diferente né, uma coisa diferente. Então têm muitas pessoas que às vezes nem gosta de casar aí, porque acha assim [...], que é grosseiro, que não é uma coisa assim... moderna (grifo nosso), mas eu acho muito importante, mas têm muitas pessoas que vem até de outras comunidades, que vem casar aí porque acha diferente né, que... uma coisa diferente, uma coisa assim mais rústica [...], eu achou muito bonito, eu gosto. (MACIEL, C. A., 2014. Informação verbal.)

Já o Sr. Antônio e D. Maria Joana, que chegaram à comunidade no final dos anos de 1980, se posicionam contrários à solução arquitetônica, até sugerindo que seu uso fosse transformado em um espaço cultural.

Ele não é um tijolo comum, ele é um tijolo próprio 'pra' (sic) tijolo à vista, né, e ele é todo frisado, [...] aí depois você faz um acabamento, então, aí ele fica um tijolo à vista, [...] aí é uma obra, uma obra à vista, agora ali não, ali é tudo normal, como se fosse 'pra' (sic) rebocar e não pode fazer mais nada, sabe, 'cê' (sic) num pode frisar, 'cê' (sic) num pode passar um verniz, 'cê' (sic) num pode fazer um acabamento [...]. (SOUZA, A. A. de, 2014. Informação verbal.)

A gente fica nervosa [...] com ela, porque a gente até já falou às vezes que o Bispo deveria até, assim, passar ela 'pra' (sic) prefeitura 'pra' (sic) ficar como patrimônio cult é, 'comé' (sic) que falal 'pra' (sic) fazer teatro, essas coisas, igual já tem aí, porquel e dar outro terreno 'pra' (sic) gente construir, 
100 Sr. João Batista foi um dos jovens que trabalhou nas obras de construção do conjunto religioso.

11 Que não é de conhecimento. porque aquela Igreja ali, eu acho assim, o Divino Espírito Santo, Ele é uma coisa muito especial, ele merece uma [...] Igreja bonita, organizada, e a gente não tem essa manutenção, assim, porque ela fica cara ali, 'pra' (sic) poder 'cê' (sic) manter ela daquele jeito, é caro, os custo, e a comunidade aqui não tem tanto dinheiro assim, a gente né, é uma comunidade mais humilde. (SOUZA, M. J. C. de, 2014. Informação verbal.)

Contextualizando essas apropriações, a igreja pode ser considerada uma produção de caráter moderno e por ter sido projetada por Lina Bo Bardi de forma específica, com leitura cultural e histórica, estabelecendo relações também particulares com o lugar, o povo e os materiais empregados, nem sempre é entendida como, de fato, moderna, principalmente por ser bastante "transgressora" e diversa das produções de outros arquitetos da época. Com isso, há aqueles que a interpretam como uma solução "pobre" de recursos, sem perceber sua intencionalidade de propor algo aparentemente simples, mas com a genialidade de um grande potencial transformador, através de uma estética diversa do habitual e pelas interações entre as pessoas e delas com o espaço. Sendo assim, pode-se perceber que justamente os membros da comunidade que estiveram engajados e à frente das obras, mostram-se os mais afetuosos, por terem criado laços mais fortes, em função dessa participação direta e intensiva.

\section{O projeto e as transformações}

Com relação ao conjunto construído, Frei Fúlvio Sabia atenta-se para a não religiosidade de Lina Bo Bardi e seu apreço pelas questões comunitárias, fato que a impulsionou a aceitar o convite para a elaboração da igreja, doando o projeto à comunidade.

Você sabe que ela não era muito religiosa não, mas ela gostava dessas iniciativas de tipo popular, não é? E aí marcamos um encontro aqui, para visitar o lugar, que era aquela área aonde tem a igreja agora e fizemos o primeiro encontro com o povo. Porque ela gostava que o povo estivesse presente. Então naquela área nós tínhamos construído um barracão de madeira, assim de tábuas, e lá com a Lina fizemos o primeiro encontro, ela mais dois jovens arquitetos [...]. (SABIA, 2013. Informação verbal.)
Segundo o Sr. João Batista ${ }^{10}$, Lina Bo Bardi apresentou dois projetos para a igreja, um convencional ${ }^{11}$ e outro redondo e singular como foi executado em acordo com a comunidade.

[...] marcadas sempre as reuniões aos domingos, ela vinha, participava com o pessoal, discutia os projetos, que que ia ser feito, 'comé' (sic) que ia ser feito. Ela apresentou... dois, dois modelos de projeto: um era aquilo como ficou, que é redondo e uma seria uma igreja tradicional. Porém, ela [...] junto com/ a comunidade combinou que fosse um, um/ uma Igreja redonda né, totalmente diferente das [...] demais, das que já tinha aqui na, na região [...]. (SILVA, J. B. da, 2014. Informação verbal.)

E o Frei italiano comenta brevemente, como Lina Bo Bardi pensou o projeto e as medidas iniciais para as obras.

E ela começou a elaborar... viu o lugar... começou a elaborar o projeto, e na ideia dela, sendo nós Franciscanos, ela queria fazer uma estrutura que assemelhasse, tivesse alguma semelhança com os nossos conventos. Então uma igreja, depois uns 'quartinhos', um claustro e as dependências com um salão para o povo, um galpão para o povo. Então foi isso que ela começou a idealizar. E naquela época, naquela área, tinha pouca casa, 'pouquinha', não é que agora tem demais, mas naquela época tinha menos ainda. E não queria que uma estrutura muito grande sobressaísse demais, não é, ao nível popular, por isso que ela sugeriu de fazer aquela estrutura de tijolinho comum sem reboque, não devia ser rebocada nem de dentro, nem de fora... eles rebocaram do lado de dentro, mas não 'tá' (sic) no projeto [...]. Então, depois fizemos mais algum encontro com o grupo representante, a comunidade e o engenheiro calculista, [...]. E aí, quando foi definitivamente aprovado o projeto, nós começamos a juntar o material, e aí começaram também os mutirões. A primeira coisa, limpamos a área, [...]. Depois o povo construiu aquele cruzeiro que ainda está lá, cruzeiro de madeira e colocou [...] - "aqui vai ser a igreja". (SABIA, 2013. Informação verbal.)

Marcelo Ferraz ainda destaca as releituras, como já apresentado, que o conjunto constrói tanto com a arquitetura e a história, principalmente da época medieval, como com outras estruturas do 
12 Quando ainda estavam utilizando o barracão de madeira do exército, antes das obras da Igreja.

13 Na verdade para Essen, na Alemanha, onde havia a sede da organização católica alemã Adveniat. cotidiano da cidade, por exemplo, o chão batido do espaço comunitário remetendo aos terreiros do Candomblé, dos quintais das casas, da relação do homem com a terra.

[...] realmente é uma obra sui generis, é claro que a gente lê nesse projeto dela, uma forte ligação com a arquitetura que ela admirava muito, que é a arquitetura medieval, uma arquitetura romana, românica, mas de configuração mais até medieval... é uma época da história das artes e da arquitetura que ela curtia muito, ela achava até que era mais interessante do que o Renascimento, porque ainda era uma coisa muito livre das questões formais, da estética construída, a estética ocidental. E ela dizia que ainda na Idade Média, o que guiava a arquitetura, era, até muito mais, a técnica, as formas eram geradas muito mais pelas soluções técnicas e tudo mais, do que por essa formalização ou conceituação estética que veio com o Renascimento. Então aquela igreja, ela tem claramente essa raiz profunda da Lina, da Lina romana, associada com essa questão popular, com essa questão de ser 'pra' (sic) gente, 'pra' (sic) uso, 'pra' (sic) todo tipo de gente, 'pra' (sic) religioso, para não religioso.

[...] o nosso contato com a comunidade foi naquele momento, com aquele povo, o Frei Fúlvio, com aqueles padres franciscanos e tal. Depois aconteceu o seguinte, com a mudança do Papa, os franciscanos foram chamados de volta para Roma, e eram uns franciscanos progressistas, legais. Eu até disse que aquela Igreja tem até um aspecto de uma igreja, eu falei, pagã uma vez, mas então podia ser panteísta, porque ela tem uma configuração de um terreiro, é um espaço generoso nesse sentido. Também fui mal interpretado quando falei isso, mas eu acho que isso não é demérito para a lgreja, é uma igreja que acolhe pessoas. O próprio espaço se parece com um terreiro, o terreiro não é só de Candomblé, o terreiro é o quintal das casas, o terreiro é pisar no solo, tocar o pé na terra, tudo isso também, simbolicamente, é uma coisa bonita, não é que é uma coisa pagã, uma coisa herege, herética, não é isso. (FERRAZ, 2013. Informação verbal.)

D. Ana Alice enfatiza ainda que Lina Bo Bardi gostava de ficar entre o povo.

[...] ela era uma pessoa assim muito, muito aberta a ficar no meio do povo, né, muito, assim, conversava com todo mundo, [...]... pessoal tem lembrança boa dela, mesmo os mais... os que na época eram mais jovens né. (PINTO, 2014. Informação verbal.)

E O Sr. Luiz Valter comenta sobre suas visitas à obra e o quanto era fácil estabelecer diálogos, o que é reforçado pelo Sr. João Batista.

Quando nós 'tava' (sic) lá em cima'12 ainda, a Lina Bo Bardi teve aqui fazendo visita 'pra' (sic) nós, 'pra' (sic) fazer já o início da construção [...] nós tiramos fotos com ela, 'mandou pra' (sic) Itália'13, acho que é 'pra' (sic) Itália, 'pra' (sic) vir uma verba de lá 'pra' (sic) começar essa igreja aí, e veio essa verba 'pra' (sic) fazer o aterro e deu 'pra' (sic) comprar aqueles 'tijolo' (sic), 60.000 tijolos que compramos aí, tijolinhos, e mais algum material.

[...] Conversava, ixi, ela conversava muito, né, ela orientava né, o jeito que era 'pra' (sic) ser feito, era muito simples, a Lina Bo Bardi era muito simples, era uma mulher muito, já de idade, mas era uma pessoa fácil demais de conversar com ela, muito simples, humilde, muito compreensiva. Uma pessoa, pelo nível dela né, era uma pessoa fácil assim da gente chegar. (SILVA, L. V. da, 2014. Informação verbal.)

[...] ela falava bem né, ela além de ser italiana, mas ela tinha um, um português bem pontual, a gente entendia bem o que ela falava. [...] ela vinha mesmo pessoalmente frequentar né, ela participava [...] das reuniões aqui, nas obras ela vinha né, inclusive a gente tinha alguns documentos né, algumas fotos e tudo né. (SILVA, J. B. da, 2014. Informação verbal.)

Isto reafirma o quanto o discurso crítico cultural de Lina Bo Bardi estava em consenso com sua atuação e relação com o povo, estabelecendo diálogos próximos e definindo assim, as soluções do projeto, sem o enaltecimento da figura do arquiteto.

Em termos construtivos, segundo Frei Fúlvio, a madeira de aroeira foi doada, tanto do desmonte de uma igreja em Monte Alegre/MG, como por um fazendeiro de Canápolis/MG. Ressalta também o início do trabalho comunitário para a construção dos muros de arrimo, dispondo o conjunto em quatro platôs, com duas áreas destinadas ao povo, o que era foco do projeto de Lina Bo Bardi. 
Depois começamos a juntar o material e o nosso Confrade estava reformando, aliás, reconstruindo a Igreja de Monte Alegre. A Igreja de Monte Alegre era toda, originariamente, de pilares de madeira. Quando os pilares de madeira não aguentavam mais, puseram ao redor da madeira, pilar de tijolos, de alvenaria. Aí, não dava mais para... então demoliram tudo, ficou só a fachada, só a fachada da frente. Em cada pilar, tinha um esteio de madeira de aroeira, as que pudemos aproveitar, vieram para cá. Tem muita pilastra de aroeira de 1800 e pouco, vieram para cá, doaram, porque assim aproveitamos a aroeira que estava lá. Outra aroeira também... nosso Bispo [...] tinha ficado cinco anos em Canápolis, conhecia um amigo lá, que tinha uns pés de aroeira... [...] nós cortamos umas árvores de aroeira boas e trouxemos para cá. Então os esteios, conforme a Lina tinha sugerido, estavam lá. Depois começamos, além de certas coisas, logo assim devagar, e o povo começou um pouco a trabalhar junto conosco, e fazer os alicerces. A primeira coisa, que era mais difícil, era fazer os vários patamares, então 'foi feito' (sic) os muros de arrimos. Primeiro os muros de arrimo, porque o terreno é inclinado. Vários níveis, a igreja, a 'casinha' e o barracão [...] e no fim, o campinho de futebol que agora construíram não sei o que, mas parece que tem ainda, por cima, tem ainda uma área, porque a Lina, ela sempre falava, não pode ocupar área toda, tem que deixar um pouco de área para o povo, o povo era igreja - o barracão e a área para menino brincar.

[...] Então, fomos construindo, [...] eu fiquei emocionado quando, depois de feitos os arrimos, construímos os alicerces, depois construímos as paredes só da igreja, [...]. Cobrimos a igreja e celebramos [...], eu tenho um pouco de dúvida, o primeiro Natal, acho que foi de 1980, não me lembro bem, [...], não tinha piso, não tinha, não tinha nada, arrumamos uns tocos, para o altar. [...] Então é isso... o primeiro altar, uma tábua, foi assim, e ficou assim por um tempo. Depois, logo foi construida a casinha, depois foi construído o barracão lá embaixo [...], mas dentro de pouco tempo. (SABIA, 2013. Informação verbal.)

Com relação aos mutirões, esses foram destacados em alguns depoimentos. O Sr. Alfredo comenta que eles aconteciam aos domingos e que realmente houve muito trabalho por parte da comunidade.
Participou, fazia, às vezes, 'mutirão' (sic) nos domingos, a gente ia para fazer aquele muro de arrimo, né, [...] aí o concreto vinha pronto para aterrar aquilo lá... a comunidade ajudou muito ali, muito.. muito. (MENEGATO, 2014. Informação verbal.)

O que é ressaltado também por Frei Fúlvio.

A coisa mais interessante é que o povo ficou envolvido na construção continuamente, tiveram muitos mutirões, né, nas coisas assim mais grosseiras, vamos dizer, furar os alicerces... carregar material, lembro quando nós trouxemos essas toras de aroeira lá de Canápolis, o caminhão, esse caminhão com guincho [...] para carregar essas toras, o povo inteiro é que ajudou, depois, foram lavradas [...] e sempre que era para colocar as toras no lugar certo, o povo é que ajudava, e assim por diante. (SABIA, 2013. Informação verbal.)

Esses mutirões construtivos da época eram respaldados por outras práticas da comunidade, como já abordado, a fim de levantar fundos para erguer as edificações, o que continua a ser praticado nos dias atuais, através de festividades e outros eventos que arrecadam verbas usadas para as necessidades da Paróquia e que também foram destinadas ao restauro e construção do centro pastoral.

Em termos das transformações, D. Conceição comenta as alterações realizadas por padre Rui e reforça a união e dedicação da comunidade.

É porque na época ele não gostava, por causa de ser tombado, e não podia mexer em muita coisa né, então ele até mexeu [...], que ela não podia ser modificada, não podia ser rebocada por dentro, e rebocou né. Depois o frei Fúlvio não ficou contente, porque o frei Fúlvio preza muito essa obra da Lina. Então ele não queria muito que fizesse isso, mas depois deu tudo certo também, o padre Rui também ficou uns sete anos, [...]. Depois que 'veio' (sic) outros padres, depois que veio o padre Mauro, padre Henrique, mas foi tudo bem, a comunidade sempre ajudou muito né, a comunidade toda é muito... até o padre Marcio fala que... assim, muitos padres tinham vontade de 'vim' (sic) para cá, porque a comunidade trabalha muito né. (MACIEL, C. A., 2014. Informação verbal.) 


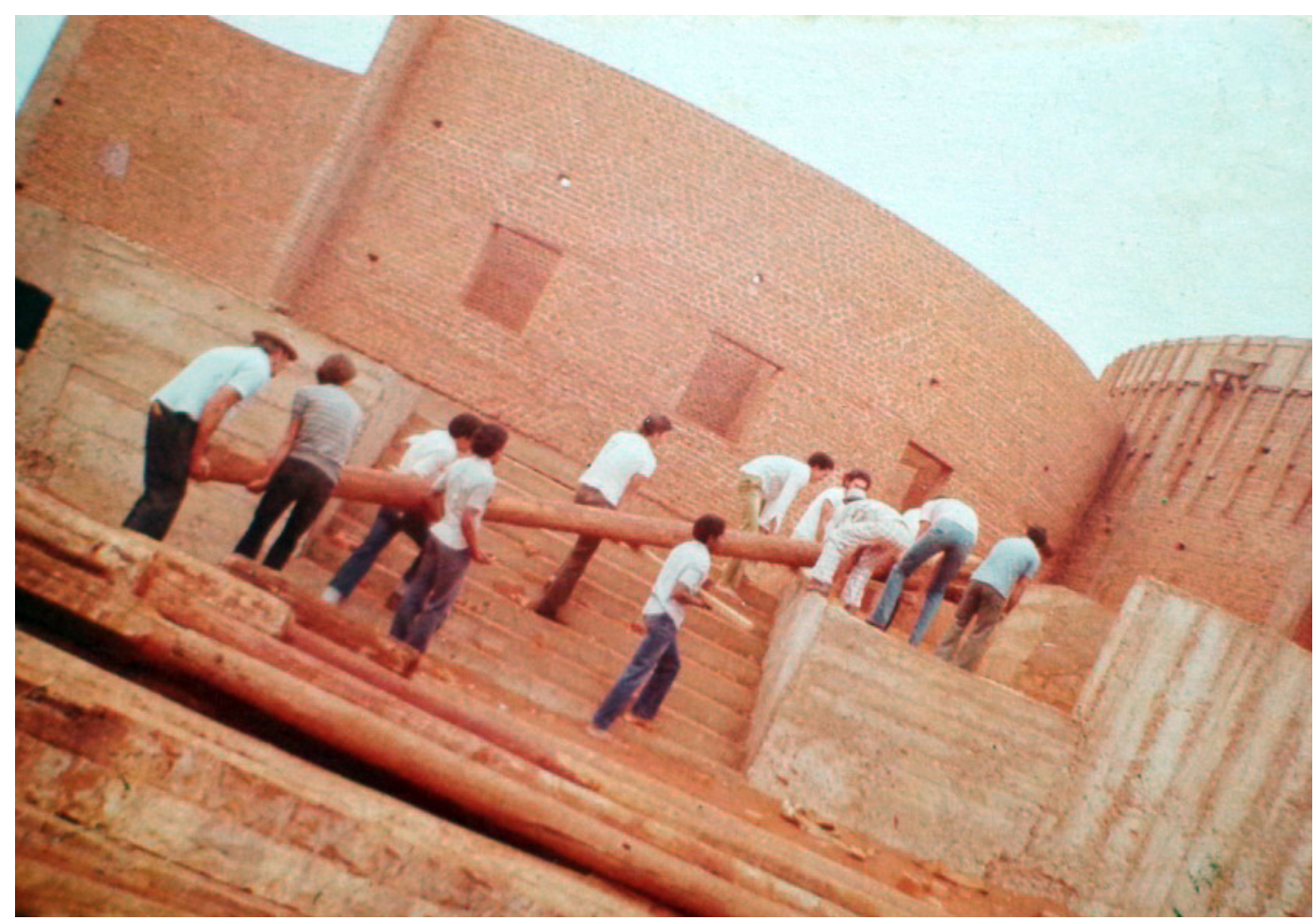

Figura 8: Mutirão para colocação do madeiramento interno da capela. Fonte: SILVA, João Batista da, 1980.

14 Posteriormente cimentado.
O arquiteto Marcelo Ferraz também recorda a atuação de padre Rui, que, por desgostar da forma da igreja, promoveu alterações significativas. E completa que, na atualidade, o conjunto passou por reforma e restauro, proposta assinada por ele e por André Vainer - coautores do projeto original.

[...] eu comecei a contar que os franciscanos vão embora, entra um padre secular que odeia a igreja e ele começa a destruir, quebrar as celas, ligar uma cela na outra para fazer um quarto grande, e foi um momento muito triste porque a igreja viveu, assim... uma pessoa que não gosta do espaço que usa, quer dizer, não dá, não há espaço que aguente isso. Ele saiu, entrou outro padre legal que infelizmente morreu, e agora tem o padre Márcio que é maravilhoso, ele adora, ele quer colocar tudo em ordem. Nesse meio do caminho, a gente conseguiu com o IEPHA, o Instituto do Patrimônio, o recurso 'pra' (sic) reformar a igreja, tanto do ponto de vista das infiltrações de telhado, o telhado tinha um ponto muito baixo... até para terminar as coisas que precisam ser terminadas. Então, ela 'tá' (sic) sendo reformada, 'tá' (sic) sendo feita, e também tirar certos puxados que foram feitos pelo outro padre, a 'garaginha' (sic), isso, aquilo, e terminar, botar o sino no campanário, botar a 'imagenzinha' (sic) do Espírito Santo no telhado, tudo isso 'tá' (sic) sendo feito... o IEPHA entrou com recurso, licitou as obras, está fazendo... o padre nos consulta sempre, a gente vai de vez em quando lá, a gente que eu digo, eu e o André Vainer. (FERRAZ, 2013. Informação verbal.)

O arquiteto ainda fala a respeito do anexo, que foi construído no platô mais baixo, onde antes existia o campinho de futebol ${ }^{14}$, ressaltando que era uma demanda da paróquia, sem comentar muito suas decisões de projeto.

E também o padre tinha uma necessidade que é de agora, não é do tempo que a igreja foi feita, mas que é com a casa paroquial. Ele precisava de um espaço e a gente falou - "como é que a gente vai encarar isso". Tudo estava cercado, o campinho já não existia, [...] e a gente resolveu construir ali um bloco, uma caixa, uma caixa de fósforos, um retângulo, uma coisa muito discreta, com um terraço em cima, que repõe de certa maneira, o piso do Campinho. É um terraço de festas, livre e 
uma construção muito discreta, assim como uma casamata, fechada. E a gente imaginou mesmo, uma coisa que fosse para ser discreta, ser diminuída, mesmo que tenha um volume grande, que pese naquela relação. E fizemos o projeto, recebemos algumas críticas, a gente sabe, assim ao longe, em Uberlândia, alguns arquitetos, isso e aquilo, mas submetemos ao patrimônio histórico, ao IEPHA, discutimos com eles e eles aprovaram [...] e o padre está satisfeito, têm salas, ele atende ali as pessoas, grupos, tem sala de atendimento psicológico, enfim, tem o trabalho que eles fazem lá e a gente respeita esse trabalho, e hoje ele está equipado com essa sala paroquial, que funciona lá embaixo, e não de uma forma precária que estava funcionando nas celinhas, ali dentro, na habitação. Isso que eu faço não é uma defesa do projeto da gente, mas é um esclarecimento, porque o projeto a gente defende sempre que for preciso, é um esclarecimento e a gente assume aquilo como um momento novo daquele conjunto, que está incorporado ao conjunto com outros materiais, a gente evitou usar o tijolinho e tal, para dizer "isso aqui foi feito, sei lá, 2010-11". (FERRAZ, 2013. Informação verbal.)

Padre Márcio também destaca essa necessidade, visto que a comunidade se ampliou com o tempo e o espaço destinado às atividades da mesma ficou insuficiente. Comenta sobre um possível projeto de salas, idealizado por Lina Bo Bardi, o qual não é de conhecimento geral e não há registros. Assim como, chama atenção para o engajamento da comunidade, de poder aquisitivo médio a baixo, em arrecadar fundos para as obras.

O André mais o Marcelo fizeram o projeto do anexo, que onde se concebia um espaço de um campo de futebol, a Lina também tinha feito um projeto de salas para encontros, para reuniões, só que hoje, hoje quando a gente vê esse projeto, ele já não atende mais, pelo crescimento e tantos grupos que nós temos na paróquia. Então o André mais o Marcelo refizeram aquele projeto, apresentaram para o IEPHA, foi aprovado e nós, num prazo de um ano, construímos esse anexo. Você pensa, aqui é um bairro de pessoas de classe media baixa, né, em um ano se levantou na comunidade, $R \$ 253.000,00$ para a construção. Então, nós fizemos o anexo e foi feita também a primeira intervenção do IEPHA, que até então, as intervenções eram todas da paróquia, e o IEPHA fez uma intervenção dos telhados, e nessa intervenção, nós trocamos todo forro de madeira da casa, o telhado da casa, do salão e da igreja, e agora, nós, com o Marcelo Ferraz, sentamos e eles apresentaram para o IEPHA um novo projeto de reforma e restauro, foi aprovado e nós conseguimos uma liberação de $R \$ 415.000,00$, se eu não estou enganado, junto à Secretaria de Cultura do Estado, por meio da fundação do IEPHA e a intervenção começou há cerca de vinte dias. (GONÇALVES, 2013. Informação verbal.)

Os membros da comunidade defendem a construção do centro pastoral:

"[...] o centro pastoral, aquilo lá era uma necessidade, havia realmente uma grande necessidade daquilo, porque o prédio cá em cima tornou-se insuficiente.. né, a pequena dependência que há ali para essa finalidade, é...tornou-se insuficiente, o movimento cresceu, a população cresceu, sempre há mais coisas, então foi muito bom a criação daquilo lá, certo? Podem inclusive desenvolver alguma coisa mais, é... assim, mais útil para a comunidade [...]. Pena que não possa ser construído em cima, porque aí, é... tira o visual, parece, aí a questão da preservação do local, é... do patrimônio. Então, aí tudo bem, isso aí não impede que se use aquela parte de cima, assim, provisoriamente com uma cobertura, faz uma barraquinha, qualquer coisa lá e tal e então 'tá' (sic) num tamanho bom". (CARVALHO, 2014. Informação verbal.)

"Muito bom mesmo, [...] eu acho que aquilo ali era uma coisa que 'tava' (sic) precisando, mas tem 'muuitos' (sic) anos, muitos anos, sabe... porque criança precisa de ter [...] um certo cuidado [...] então, sendo naquele local específico, [...] então foi muito bom o centro pastoral..." (PINTO, 2014. Informação verbal.)

"[...] é muito bom também, porque precisava de lugar, de espaço 'pra' (sic) dar aulas, catequese, ter salas de reuniões, né, e num 'tava' (sic) tendo, e onde ia fazer?, né, 'vamo' (sic) supor, no lugar de uma quadra de futebol, um salão é muito melhor, muito melhor aproveitável [...], muito bom, eu aprovei muito bem aquela obra que eles fizeram ali, [...]. (SILVA, L. V. da, 2014. Informação verbal.)

"Ampliação do centro pastoral, todos padres queriam fazer alguma coisa, mas nenhum conseguia né. 
Esse centro pastoral foi muito bom, porque teve, criou salas para catequese, para reuniões, a própria secretaria né, deixando as salas de cima [...] para o pessoal trabalhar com fraldas [...]. (SOUZA, M. R. de, 2014. Informação verbal.)

Padre Márcio ainda fala de sua intenção em retornar, o máximo possível, a originalidade do conjunto e o que foi proposto e aprovado pelo IEPHA-MG, com relação à reforma e restauro.

No projeto de reforma lá na igreja, desde que eu cheguei, qual que foi a minha intenção - eu apresentei para o Marcelo e para o André - é de retomar a originalidade da obra. [...] Nós fizemos o que não existia - o projeto de incêndio da obra. Quando houve a interdição, uma das exigências é que se fizesse um projeto de incêndio, esse projeto foi feito e agora, toda a parte elétrica e hidráulica e incêndio está sendo revista nessa reforma. [...] O reboco nós vamos manter, é o entendimento do IEPHA, que depois de tantos campinho de futebol, com o centro comunitário ao fundo. Fonte: IEPHA/MG, 1997, p.68. Data indefinida. anos, está aí caracterizado. Aqui é interessante, porque, como o Marcelo mais o André, são postos como coautores, aliás, eu já ouvi alguns dizerem que isso é algo inédito, num projeto de arquitetura, se falar em coautoria, mas eles são coautores, eles estavam junto com a Lina em toda a concepção do projeto, como eles estão vivos, e ainda são jovens, transitam muito por aqui e a gente tem um contato permanente, é muito fácil, porque eles têm autoridade da autoria do projeto e eles têm uma relação de muito diálogo, são figuras muito abertas, então é fácil requisitar junto com eles. (GONÇALVES, 2013. Informação verbal.)

De modo geral, o processo de uso e ocupação da igreja, assim como o crescimento da comunidade proporcionaram necessidades atuais não mais compatíveis com as dimensões das edificações projetadas por Lina Bo Bardi, nos anos de 1970 a 80. O que cabe discutir é se o centro pastoral construído é coerente com as intenções originais, que, por exemplo, propunham um campo de futebol aberto para a comunidade e edifícios mais permeáveis no tecido urbano, com dimensões modestas que se integrassem à paisagem de habitações, em maioria, unifamiliares.

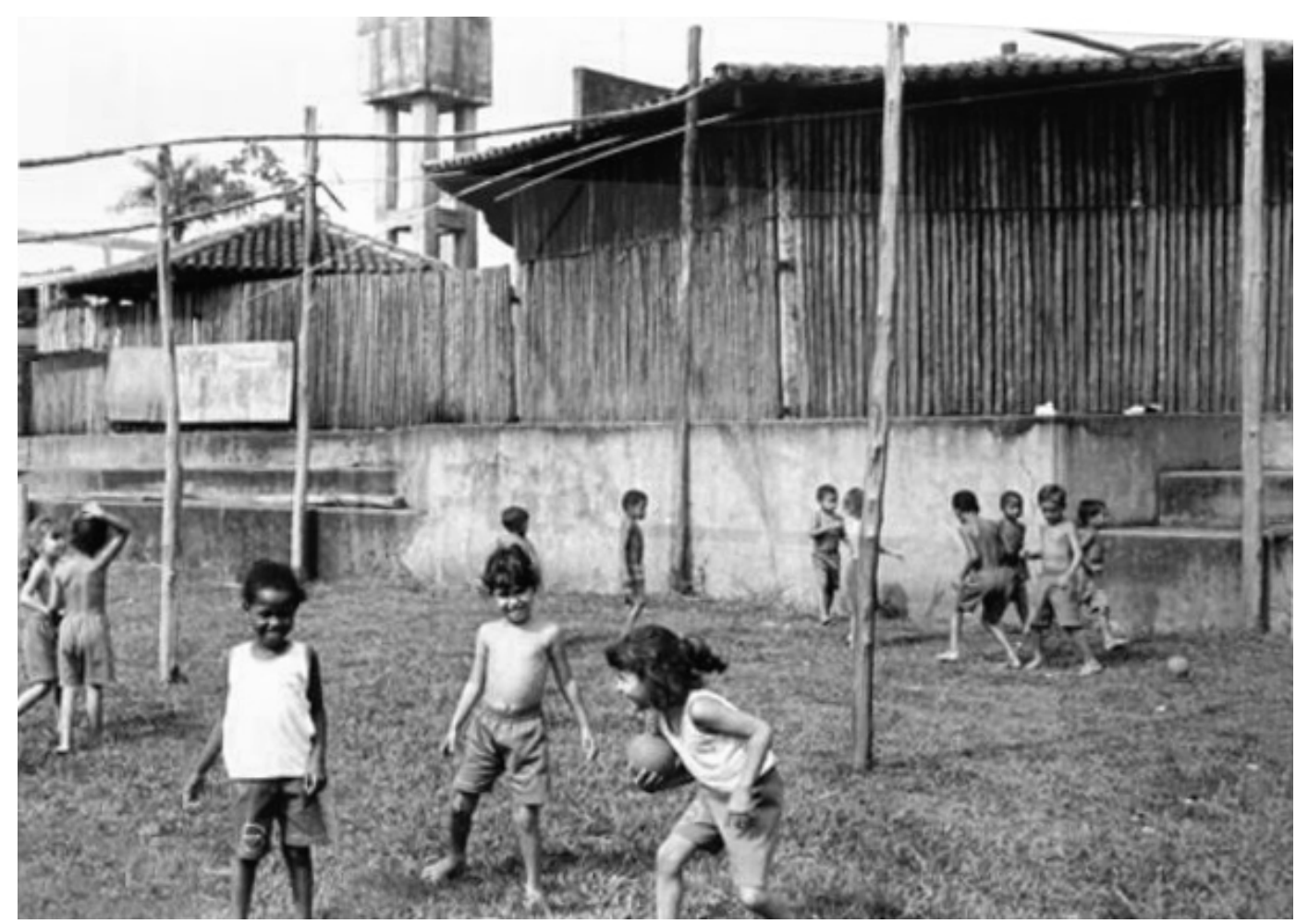


15 Época em que atuou em Salvador e fez uma expedição pela cultura popular do Nordeste.

\section{Considerações finais}

Dona Lina, como era carinhosamente chamada por muitos, imbuía-se das sensibilidades mais simples, profundas e transformadoras do povo e sua cultura popular. Suas análises e aplicações práticas, ainda nos anos de $1950^{15}$, reivindicavam a riqueza e importância dessas produções, as quais somente passaram a ter reconhecimento, de fato, no Brasil, a partir da Constituição Federal de 1988, que proporcionou grandes avanços na valorização da cultura popular brasileira.

Nesse sentido, pode-se dizer que, Lina Bo Bardi criou nos anos de 1976 a 1982, um edifício que transpõe a cultura popular, de forma simbólica, em arquitetura, ao definir um projeto que se comunicava com as pessoas, que transcendia suas diversidades culturais e características do lugar, representando-as, e que foi, de fato, construído no universo coletivo.

E, através do envolvimento com a comunidade ao longo de mais de dois anos (julho de 2012 a outubro de 2014), foi possível entender o quanto muitos ainda mantêm laços afetivos, gostam e admiram a arquitetura edificada e permanecem engajados nas atividades e cuidado com o espaço. Inclusive, seus membros têm consciência da importância da produção de Lina Bo Bardi, o caráter singular da igreja e o significado da proteção por tombamento.

Sendo assim, este estudo se propôs a definir na contemporaneidade, uma nova leitura dessa relação - cultura popular e arquitetura - através do registro das diversas memórias, dando voz para aqueles, muitas vezes esquecidos, que participaram e ainda participam de forma ativa do processo de ocupação do lugar, e ressaltando, que são eles que realmente geram a vitalidade do edifício ao longo do tempo e mantêm seu caráter coletivo e popular

O olhar transformador também foi construído neste diálogo, que possibilitou compreender o quanto esta comunidade estava às margens de discussão do conjunto arquitetônico. Isto pode ser explicitado pelo contato inicial com a secretária da paróquia, que tinha certo receito e resistência em oferecer informações para a pesquisadora, que se apresentou como arquiteta. Ao longo do tempo foi possível construir uma relação de confiança e participar de forma mais próxima e amigável da vida dessas pessoas, resultando na presente pesquisa. Deste fato, que também surgiu a necessidade de colocar em questão a figura do arquiteto que, muitas vezes se esquece de que a arquitetura é feita para pessoas e está muito além da própria edificação e/ou intervenção urbana. No caso da Igreja Divino Espírito Santo do Cerrado، isto ficou bem claro, pois os profissionais da área principalmente os locais, criticam as transformações ocorridas e a comunidade, a qual não é, muitas vezes nem por eles conhecida e que tem suas necessidades e demandas próprias de uso do espaço.

\section{Referências bibliográficas}

BARDI, Lina Bo; ALMEIDA, Edmar de; FERRAZ, Marcelo Carvalho [coord.]. Igreja Espírito Santo do Cerrado. Portugal: Editorial Blau, 1999.

BARDI, Lina Bo; FERRAZ, Isa Grinspum [org.]. Tempos de grossura: o design do impasse. 1.ed. São Paulo: Instituto Lina Bo e P. M. Bardi, 1994

BOSI, Ecléa. Cultura de massa e cultura popular: leitura de operárias. Petrópolis: Vozes, 1986

Memória e sociedade: lembrança de velhos. 3.ed São Paulo: Companhia das letras, 1994.

CANDAU, Joël. Memória e identidade. Tradução: Maria Leticia Ferreira. São Paulo: Contexto, 2011.

FERRAZ, Marcelo Carvalho. Lina e a religiosidade. p. 172 173. In: INSTITUTO Estadual do Patrimônio Histórico e Artístico de Minas Gerais - IEPHA/MG. Processo de Avaliação para Tombamento: Igreja do Espírito Santo do Cerrado, Município de Uberlândia. Belo Horizonte, 1997.

HALBWACHS, Maurice. A memória coletiva. Tradução: Beatriz Sidou. São Paulo: Centauro, 2003.

HARVEY, David. Condição pós-moderna: uma pesquisa sobre as origens da mudança cultural. Tradução: Adail Ubirajara Sobral e Maria Stela Gonçalves. 5.e. São Paulo: Edições Loyola, 1992.

INSTITUTO Estadual do Patrimônio Histórico e Artístico de Minas Gerais - IEPHA/MG. Processo de Avaliação para Tombamento: Igreja do Espírito Santo do Cerrado, Município de Uberlândia. Belo Horizonte, 1997.

LOW, Setha. M. Social Sustainability: People, History and Values. p.47-64. In: TEUTONICO, J. M.; MATERO, F. Managing Change: sustainable approaches to the conservation of the built environment. Los Angeles: The Getty Conservation Institute, 2001.

PEREIRA, Juliano Aparecido. Lina Bo Bardi, 1958-1964. Uberlândia: EDUFU, 2008.

ROSSETTI, Eduardo Pierrotti. Tensão moderno/popular em Lina Bo Bardi: nexos de arquitetura. Salvador: Dissertação de Mestrado, FAUFBA, 2002.

RUBINO, Silvana; GRINOVER, Marina [org.] Lina por es crito. Textos escolhidos de Lina Bo Bardi. São Paulo: Cosac Naify, 2009 
SILVA, Natália Achcar Monteiro. Um olhar sobre a Igreja Divino Espirito Santo do Cerrado. Belo Horizonte: Dissertação de Mestrado, EAUFMG, 2014

\section{Documentos sonoros}

CARVALHO, Alysson de. Entrevista V. [jan. 2014]. Entrevistador: Natália Achcar Monteiro Silva. Uberlândia, 2014. 1 arquivo .m4a (21 min21seg). A entrevista na íntegra encontra-se transcrita no Apêndice E da dissertação.

COELHO, Geraldo Lima. Entrevista IX. [abr. 2014]. Entrevistador: Natália Achcar Monteiro Silva. Uberlândia, 2014. 1 arquivo .m4a (15min15seg). A entrevista na íntegra encontra-se transcrita no Apêndice E da dissertação.

FERRAZ, Marcelo Carvalho. Entrevista III. [out. 2013]. Entrevistador: Natália Achcar Monteiro Silva. São Paulo, 2013. 1 arquivo .m4a (29min28seg). A entrevista na íntegra encontra-se transcrita no Apêndice C da dissertação.

GONCALVES, Márcio Antônio. Entrevista II. [mai. 2013]. Entrevistador: Natália Achcar Monteiro Silva. Uberlândia, 2013. 2 arquivos .3ga (22min26seg). A entrevista na íntegra encontra-se transcrita no Apêndice $\mathrm{B}$ da dissertação.

MACIEL, Sebastião; MACIEL, Conceição Aparecida. Entrevista XIII. [jan. 2014]. Entrevistador: Natália Achcar Monteiro Silva. Uberlândia, 2014. 1 arquivo .m4a (10min56seg). A entrevista na íntegra encontra-se transcrita no Apêndice E da dissertação.

MENEGATO, Alfredo. Entrevista IV. [jan. 2014]. Entrevistador: Natália Achcar Monteiro Silva. Uberlândia, 2014. 1 arquivo .m4a (18min19seg). A entrevista na íntegra encontra-se transcrita no Apêndice $D$ da dissertação.

PINTO, Ana Alice Maria. Entrevista VI. [abr. 2014]. Entrevistador: Natália Achcar Monteiro Silva. Uberlândia, 2014.
2 arquivos .m4a (19min3seg). A entrevista na íntegra encontra-se transcrita no Apêndice $E$ da dissertação.

SABIA, Fúlvio. Entrevista I. [fev. 2013]. Entrevistador: Natália Achcar Monteiro Silva. Uberlândia, 2013. 1 arquivo .3ga (1h02min45seg). A entrevista na íntegra encontra-se transcrita no Apêndice $B$ da dissertação.

SANTOS, Ana Maria Sales dos. Entrevista VII. [jan. 2014] Entrevistador: Natália Achcar Monteiro Silva. Uberlândia, 2014. 1 arquivo .m4a (16min16seg). A entrevista na íntegra encontra-se transcrita no Apêndice E da dissertação.

SILVA, João Batista da. Entrevista X. [abr. 2014]. Entrevistador: Natália Achcar Monteiro Silva. Uberlândia, 2014. 1 arquivo .m4a (08min14seg). A entrevista na íntegra encontra-se transcrita no Apêndice E da dissertação.

SILVA, Luiz Valter da. Entrevista XI. [abr. 2014]. Entrevistador: Natália Achcar Monteiro Silva. Uberlândia, 2014. 1 arquivo .m4a (15min26seg). A entrevista na íntegra encontra-se transcrita no Apêndice E da dissertação.

SOUZA, Antônio Alves de; SOUZA, Maria Joana Cândida de. Entrevista VIII. [abr. 2014]. Entrevistador: Natália Achcar Monteiro Silva. Uberlândia, 2014. 1 arquivo .m4a (30min28seg). A entrevista na íntegra encontra-se transcrita no Apêndice E da dissertação.

SOUZA, Marcos Ramardi de. Entrevista XII. [jan. 2014] Entrevistador: Natália Achcar Monteiro Silva. Uberlândia, 2014. 1 arquivo .m4a (06min49seg). A entrevista na íntegra encontra-se transcrita no Apêndice E da dissertação.

TUNDISI, Sonia Maria dos Santos. Entrevista XIV. [abr 2014]. Entrevistador: Natália Achcar Monteiro Silva. Uberlândia, 2014. 1 arquivo .m4a (08min18seg). A entrevista na íntegra encontra-se transcrita no Apêndice $\mathrm{E}$ da dissertação. 